\title{
Cobalt and Nickel Separation in Hydrometallurgy using Clinoptilolite as Ion- Exchanger
}

\author{
Banza Musamba*, John Kabuba and Hilary Rutto
}

\begin{abstract}
Cobalt and nickel have similar physical and chemical properties that makes their separation a serious problem in hydrometallurgy. In this work, modified clinoptilolite as ion exchanger has been identify for selective separation of cobalt from nickel. The characterization of clinoptilolites before and after modification was done using Scanning Electron Microscope (SEM), Fourier Transform Infrared spectroscopy (FTIR), X-ray fluorescence (XRF) and X-ray diffraction (XRD). The results showed that the separation of cobalt from nickel strongly depend on $\mathrm{pH}$, initial concentration, mass of the adsorbent, particle sizes and temperature. High separation was obtained under following conditions $\mathrm{pH} 6$, initial concentration $600 \mathrm{mg} / \mathrm{L}$, mass of the adsorbent $10 \mathrm{~g}$, particle sizes $1 \mathrm{~mm}$ and temperature $25^{\circ} \mathrm{C}$. The equilibrium sorption isotherms were analyzed by the Langmuir and Freundlich. The results showed that Langmuir isotherm describes better the adsorption process. The pseudo-first and second order model were used in analyzing kinetic data, absorption kinetics obeyed the second Pseudo order model that indicate that the rate limiting step for the process involves chemical reaction. Thermodynamic parameters such as Gibb's free energy change $\left(\Delta \mathrm{G}^{\mathrm{o}}\right)$, enthalpy change $\left(\Delta \mathrm{H}^{\mathrm{o}}\right)$ and entropy change $\left(\Delta \mathrm{S}^{\mathrm{o}}\right)$ were calculated and negative results revealed that the process was spontaneous and exothermic.
\end{abstract}

Keywords-Clinoptilolites, modification, ion exchanger, cobalt and nickel separation, hydrometallurgy.

\section{INTRODUCTION}

The hydrometallurgical industry produces many types of streams, increasing cost and required more effective method for cleaning these wastes. The recovery of heavy metals from the hydrometallurgical effluent stream it is very important. The effective recovery of these metals is possible only if the separation process is selective enough [1].

Cobalt can be used in alloys for airplane engine parts (corrosion resistant), electroplating, batteries, stainless steel and to treat cancer and anaemia because cobalt stimulates the red blood cells production. Nickel can be used in the manufactured of coins, stainless steel, corrosion resistant alloys such as

Manuscript received September 4, 2017.

*Banza Musamba is with the Department of Chemical Engineering, Vaal University of Technology, Vanderbijlpark, Private Bag X021 (e-mail: banzajeanclaude@gmail.com).

J. Kabuba is with the Department of Chemical Engineering, Vaal University of Technology, Vanderbijlpark, Private Bag X021 (e-mail: johnka@ vut.ac.za).

H. Rutto is with the Department of Chemical Engineering, Vaal University of Technology, Vanderbijlpark, Private Bag X021 (e-mail: hilaryr@ vut.ac.za).
(Monel, Inconel and Invar), nickel-cadmium batteries and treatment of sea water into fresh water at the desalination plant [2].

Cobalt and nickel are inseparable in aqueous solution. Their position in the periodic table as transition metal result in similar chemical performance and therefore their separation becomes difficult. In aqueous dilute solution nickel and cobalt exist as $\mathrm{Ni}^{2+}$ and $\mathrm{Co}^{2+}$ hexahydrated; the rate exchange of water on nickel is very lower than cobalt. The complex ion formation proceeds much easily with $\mathrm{Co}^{2+}$ than $\mathrm{Ni}^{2+}$ [3].

Several methods have been used for the separation processes. Most of them are physico- chemical processes and these include precipitative, separation method using resins ion exchanger, solvent extraction and pressure hydrogen [4]. In general, these methods have been found to be only partially and not economically feasible for the separation of cobalt and nickel [5].

This project has identified the high potential of clinoptilolite in separating cobalt and nickel from hydrometallurgical industrial wastewater stream due to their high ion exchange abilities, simple operation, minimal waste generation, low costs and availability. Clinoptilolites could be used on a large scale as ion exchanger for heavy metals from industrial effluent. It can be modified and regenerated. The metal ions adsorbed by the clinoptilolites can be recovered and used industrially for several applications $[6 ; 7]$.

The ion exchange is defined as the reversible exchange of ions between two or more phases, one of which is liquid phase and solid phase. The ion exchanger is not soluble in the medium in which the process is taking place. Ion exchanges processes are rapid and follow the reaction in the Eq. (1) and (2), however the kinetics of reaction become uncontrollable and difficult in heterogeneous systems. The two reactions show the ion exchange between the ion in solution and the clinoptilolites [8].

$$
\begin{aligned}
& \left.\left.X^{+} Y \text { (clinoptilolite }\right)+C^{-}(\text {solution }) \leftrightarrow X^{+} C^{-} \text {(clinoptilolite }\right) \\
& +Y(\text { solution }): \text { anionic exchanger } \\
& X^{-} Y^{+} \text {(clinoptilolite) }+C^{+} \text {(solution) } \leftrightarrow X C^{+} \text {(clinoptilolite) } \\
& +Y^{+} \text {(solution): cationic exchanger }
\end{aligned}
$$

Clinoptilolite is one of the most abundant forms of zeolite that is found naturally on earth. It is stable at high temperature [9] gave the typical formula for the clinoptilolite as $\mathrm{M}_{2 / \mathrm{n}} \mathrm{O} \cdot \mathrm{Al}_{2} \mathrm{O}_{3} \cdot \mathrm{xSi}_{2} \cdot \mathrm{yH}_{2} \mathrm{O}$. The atomic structure of clinoptilolite is 
based on three- dimensional frameworks of silica and alumina tetrahedra. Clinoptilolites is inorganic with a strong attraction for cations of transition metals series in the periodic table. The ion exchange property of clinoptilolites has been attributed to its aluminosilicate structure. Isomorphous replacement of $\mathrm{Al}$ with $\mathrm{Si}$ in the structure results in negative charge [10]. This negative charge is stabilized by alkaline earth cations of $\mathrm{Ca}^{2+}, \mathrm{K}^{+}, \mathrm{Na}^{2+}$ and $\mathrm{Mg}^{2+}$ in the zeolite [11].

\section{EXPERIMENTAL}

\section{A. Materials and Solution}

The clinoptilolite used in this study was supplied by Pratley Mining Company south Africa. The clinoptilolite was first washed in distilled water to remove fines and impurities and dried in the oven at $60^{\circ} \mathrm{C}$ for 48 hours. Clinoptilolites particles was crushed and screened through a range of sieves, only particles from 1000- $2500 \mu \mathrm{m}$ were used in the study. The sieves were shaken for 10 minutes and for Clinoptilolites characterization $75 \mu \mathrm{m}$ particles was used. The powder was then characterized using an XRD (Phillips X'pert Model 0993), XRF (Phillips Magix Pro), FTIR (Varian 7000) and SEM (Philips XL 30FEG) before and after clinoptilolites modification.

The synthetic solution was prepared using cobalt chloride hexahydrated and nickel chloride hexahydrated. Hydrochloric acid and sodium hydroxide was used to adjust the $\mathrm{pH}$. The modification of clinoptilolites was done using $\mathrm{NaOH}$, Ethylenediaminetetraacetic acid (EDTA) and succinic acid. All the chemicals used were analytical grade reagents from sigma Aldrich. The clinoptilolite was modified by contacting them to $2 \mathrm{M}$ of $\mathrm{NaOH}$ for 48 hours and 2M EDTA for 72 hour at $25^{\circ} \mathrm{C}$ Then dried at $60^{\circ} \mathrm{C}$ for 24 hours. Lastly, modified clinoptilolites contacting with succinic acid for 72 hours then dried at $50^{\circ} \mathrm{C}$ temperature.

\section{B. Experimental Procedure}

The ion exchange process on the clinoptilolite was performed in a thermostatic shaker at $180 \mathrm{rpm}$. A mass of clinoptilolites 2 to $10 \mathrm{~g}$ was contacted in conical flask with $110 \mathrm{ml}$ solution that contains Cobalt and Nickel cations. The metal ion concentration 50 to $500 \mathrm{mg} / \mathrm{L}$, the particles size 1000 to $2500 \mu \mathrm{m}$ and temperature 25 to $55^{\circ} \mathrm{C}$. The $\mathrm{pH}$ values were adjusted from 3 to 9. Every hour for a 5-hour period, $10 \mathrm{ml}$ of the suspension was taken and filtered from the mixture and tested for ion concentration using the atomic adsorption spectrophotometer (AAS). The experiment was left to run for a period of 24 hours to determine the equilibrium concentrations.

The performance of the clinoptilolite at exchanging heavy metals in the solution was assessed by calculating the percentage.

The Equation (3) will be used for the heavy metals removed

$$
\%=\frac{\left(C_{a}-C_{b}\right)}{C_{a}} \times 100
$$

where $C_{a}$ and $C_{b}$ are the initial ion concentration and final ion concentration of the solution, respectively.
The mass of removal metal ion per gram of the solvent was calculated by the Eq. (4):

$$
q_{e}=\frac{\left(C_{a}-C_{b}\right)}{M} x V
$$

where $\mathrm{V}$ and $\mathrm{M}$ are the volume of solution $(\mathrm{mL})$ and amount of sorbent $(\mathrm{g})$, respectively.

\section{RESULTS AND DISCUSSION}

\section{A. X-Ray Fluorescence (XRF)}

$\mathrm{XRF}$ analysis showed that clinoptilolites was silico based zeolites when taking in account the major component which was $\mathrm{SiO}_{2}$ for both natural and modified clinoptilolites. The elemental composition results revealed that the composition of amorphous $\mathrm{SiO}_{2}$ in the natural clinoptilolites was 65.54 and 67.78 after modification. The ratio of $(\mathrm{Na}+\mathrm{K}) / \mathrm{Ca}$ was 3.93 and 3.33 for natural and modified clinoptilolites respectively. The increase of the ratio after modification is the result of EDTA [12]. And effect of succinic acid in clinoptilolite [13]. It can be seen that the crystallinity of clinoptilolites is affected by the modification.

\section{B. Scanning Electron Microscope (SEM)}

SEM image of natural and modified at the same magnification were presented in Fig. 1. The SEM image of modified clinoptilolite (B) shows a typical morphology of sedimentary. For both natural and modified cavities of different shapes and sizes could be observed. The natural clinoptilolite indicates the presence of small globular particles and modified shows bigger and irregular sizes [14]. This can be attributed to the fact that modification is a surface phenomenon and EDTA and succinic acid chemically modifies the clinoptilolite.

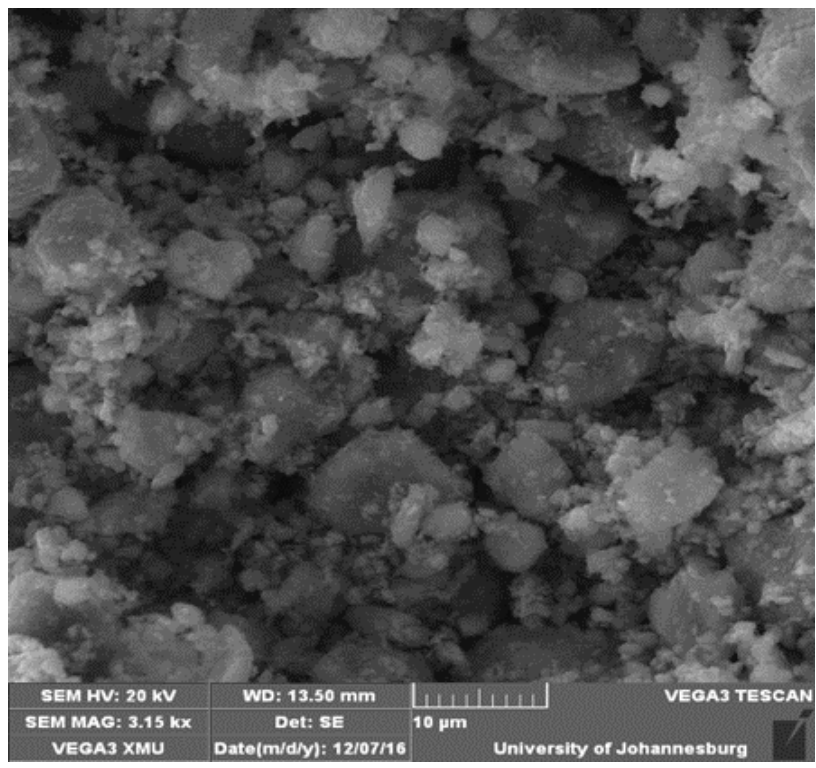

(A) 


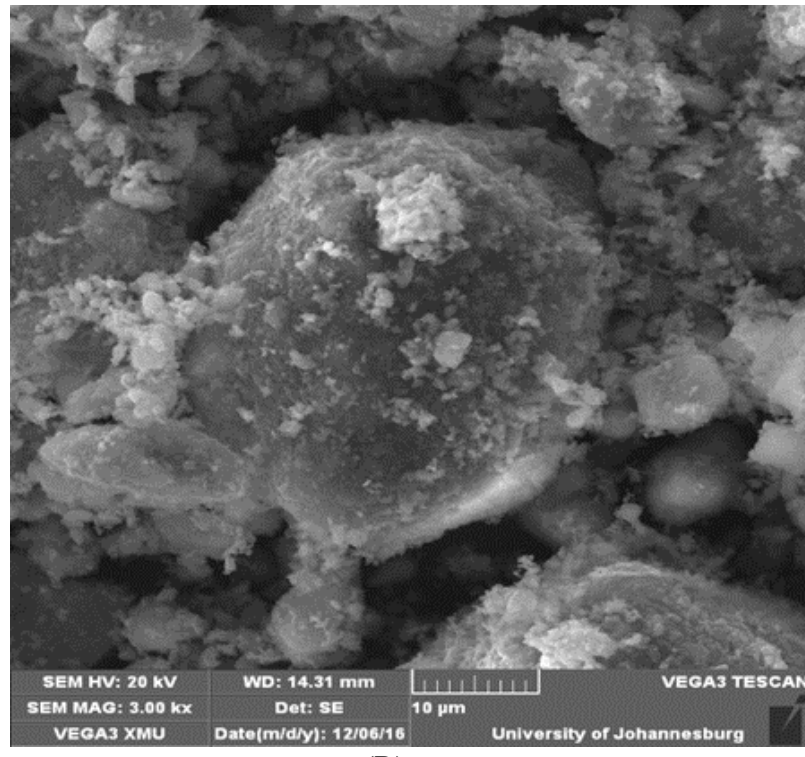

(B)

Fig. 1. SEM images for natural clinoptilolite (A) and modified clinoptilolite (B)

\section{X-Ray Diffraction (XRD)}

The XRD pattern of clinoptilolite was illustrated in Fig. 2 for natural clinoptilolite. Natural clinoptilolites was found to be monoclinic, crystalline and heulandite with highest peak occurring at $2 \theta$ value of 25 . The modified clinoptilolite in Fig. 3 has also monoclinic crystallography too with highest crystalline peak appearing at $2 \theta$ value of 10 . Most of peaks occurring between 10- 40 .

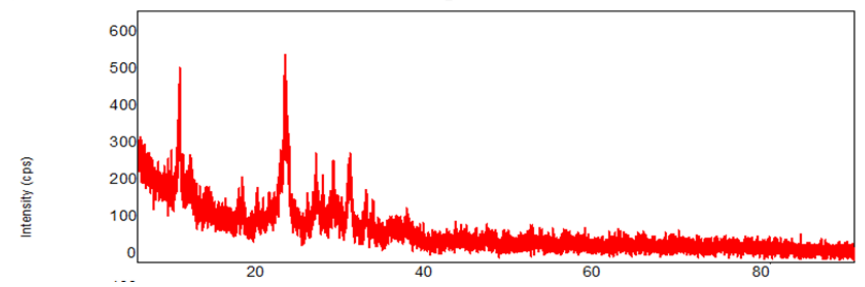

Fig. 2. XRD patterns for natural clinoptilolite

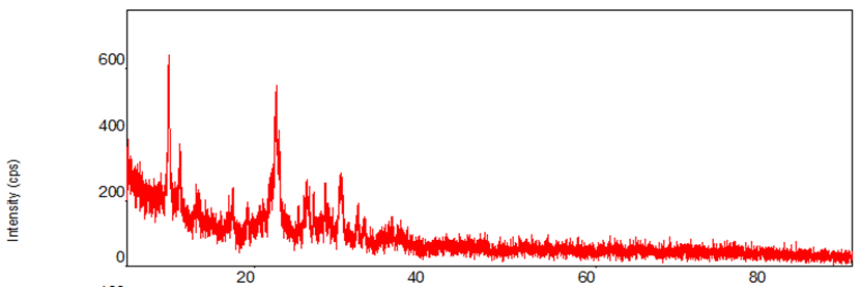

Fig. 3. XRD patterns for natural clinoptilolite

\section{Fourier Transform Infrared Spectroscopy (FTIR)}

Peaks positions were observed at 3413,1632, 1020 and 792 $\mathrm{cm}^{-1}$ in Fig. 4 and peaks 3415, 2925, 2856, 1635, 1022 and 788 $\mathrm{cm}^{-1}$ in Fig. 5. Bands connected with $\mathrm{Si}-\mathrm{O}(\mathrm{Al})$ and $\mathrm{Si}-\mathrm{O}(\mathrm{Si})$ vibrations in tetraedra or alumino and silicon oxygen (range of 1100 to $450 \mathrm{~cm}^{-1}$ ). Bands due to the presence of zeolitique water (range 1700 to $3800 \mathrm{~cm}^{-1}$ ) and bands due to the lattice vibration of structural unit $\left(650-750 \mathrm{~cm}^{-1}\right)$. Bands due to $\mathrm{C}=\mathrm{C}$ and $\mathrm{C}-\mathrm{O}$ stretching vibration (range 1100 to $2900 \mathrm{~cm}^{-1}$ ). The position of the main band at $1029 \mathrm{~cm}^{-1}$ shift to $1022 \mathrm{~cm}^{-1}$ is due to the stretching vibration of $\mathrm{Si}-\mathrm{O}(\mathrm{Al})$ and $\mathrm{Si}-\mathrm{O}(\mathrm{Si})$.

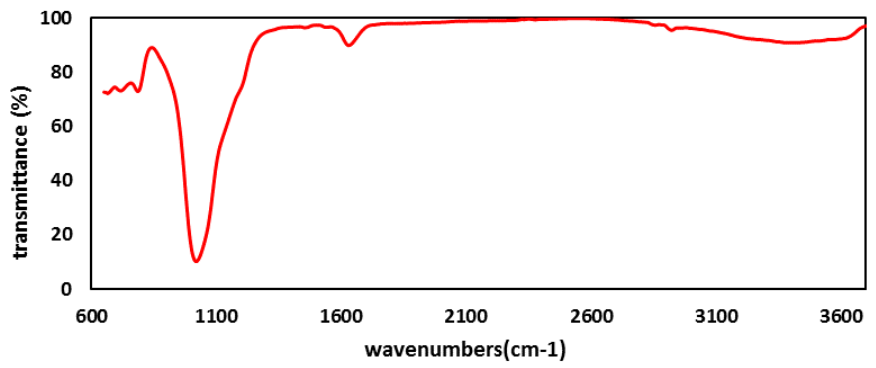

Fig. 4. FTIR patterns of natural clinoptilolite

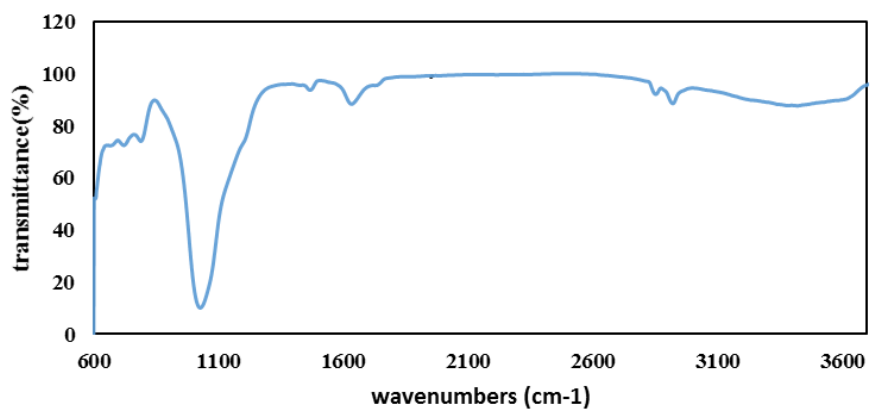

Fig. 4. FTIR patterns of modified clinoptilolite

\section{E. Effect of $p H$}

The effect of $\mathrm{pH}$ on the metals removal by modified clinoptilolites was studied in the range of 2 to 9 and keeping another parameters constant [14]. The influence of $\mathrm{pH}$ on cobalt and nickel separation was illustrated in Fig. 6. The removal efficiency of cobalt and nickel increase with an increase of $\mathrm{pH}$ from 3 to 6 . The maximum removal efficiency for cobalt and nickel was $97 \%$ and $36 \%$ respectively. This is due to electrostatic force between the negatively charge of the modified clinoptilolites and positives charge of metals. Stronger acidic $\mathrm{pHs}$ protons present in the solution compete with cobalt cations compare to nickel cations for sites available of the modified clinoptilolites which gave a good separation between nickel and cobalt. Decrease in removal efficiency of cobalt $87 \%$ and nickel $27 \%$ at $\mathrm{pH} 9$ is due to occupation of sites available of the modified clinoptilolite [14].

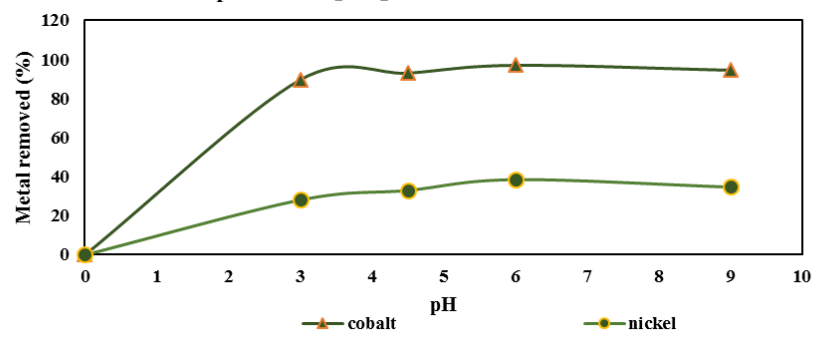

Fig. 6. Effect of $\mathrm{pH}$ on the removal of cobalt and nickel onto modified clinoptilolites

\section{F. Effect of Mass of Adsorbent}

The Adsorbent dosage is an important parameter in the ion exchange process because is influencing the capacity of modified clinoptilolites for a given initial concentration. In this 
study, the clinoptilolite dosage was varied from $2 \mathrm{~g}$ to $10 \mathrm{~g}$. $\mathrm{Co}^{2+}$ ions were removed from the aqueous solution at small the dosage of modified clinoptilolites. When the dosage of modified clinoptilolites was increased from 2 to $10 \mathrm{~g}$ the removal percentage increases from $78 \%$ to $98 \%$ for cobalt and $16 \%$ to $37 \%$ for nickel. The percentage removal of cobalt and nickel increases with the increase of modified clinoptilolites dosage is due to the to the increase in active site on the modified clinoptilolites making the penetration of cobalt ions easy compare to nickel. The highest removal efficiency was obtained at $10 \mathrm{~g}$ with $98 \%$ of cobalt. For further experiment the amount of clinoptilolites was selected as $10 \mathrm{~g}$.

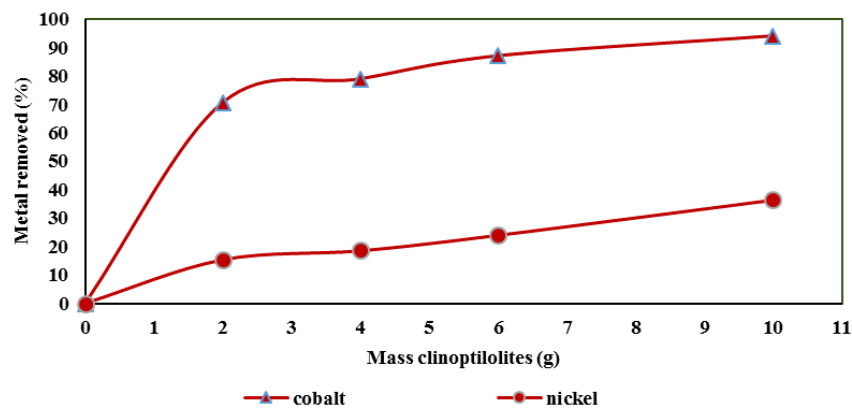

Fig. 7. Effect of mass of clinoptilolites on the removal of cobalt and nickel onto modified clinoptilolites

\section{G. Effect of Particles Size}

The effect of $\mathrm{pH}$ on the metals removal by modified clinoptilolites was studied in the range of $1000 \mu \mathrm{m}$ to $2500 \mu \mathrm{m}$ and keeping another parameters constant. The influence of particles size on cobalt and nickel separation was illustrated in Fig. 8. The removal efficiency of cobalt and nickel decreases with an increase of particles sizes. At $1000 \mu \mathrm{m}$ the percentage removal of cobalt was $95 \%$ and nickel $34 \%$ then decrease to $85 \%$ for cobalt and $21 \%$ for nickel at $2500 \mu \mathrm{m}$. The increase in efficiency of removal for cobalt is due to the increase in external surface area of the small particles size of the modified clinoptilolites. The maximum removal efficiency for cobalt and nickel was $95 \%$ and $34 \%$ respectively for $1000 \mu \mathrm{m}$.

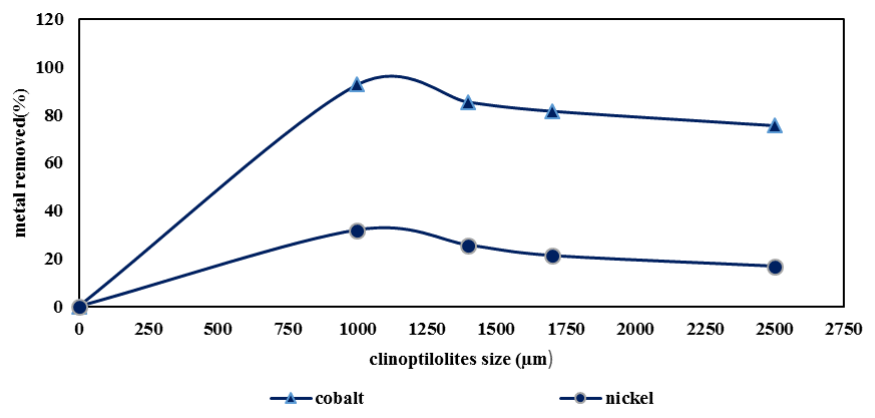

Fig. 8. Effect of clinoptilolites sizes on the removal of cobalt and nickel onto modified clinoptilolites

\section{H. Effect of ion Concentration}

The effect of initial concentration for cobalt and nickel removal from aqueous solution by modified clinoptilolites was determine. The cobalt removal efficiency increase from $77 \%$ to $97 \%$ and nickel from $20 \%$ to $35 \%$ in the initial concentration from $50 \mathrm{mg} / \mathrm{L}$ to $600 \mathrm{mg} / \mathrm{L}$ due to the equilibrium nature of
Co-clinoptilolites modified and ion exchange process [15]. then decrease to $90 \%$ for cobalt and $31 \%$ for nickel at $900 \mathrm{mg} / \mathrm{L}$ this reduction may be resulted from saturation of the modified clinoptilolites surface.

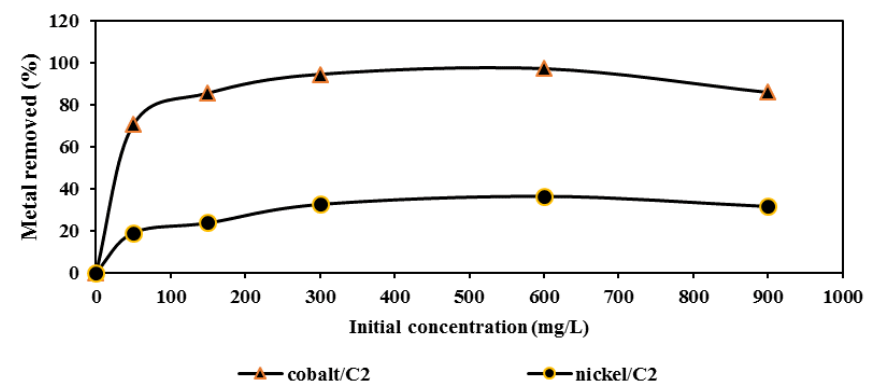

Fig. 9. Effect of initial concentration on the removal of cobalt and nickel onto modified clinoptilolites

\section{Effect of Temperature}

Temperature is an important parameter for the removal of heavy ions metal in the solution. Because temperature of the of the solution can affect the solution/solid interface. The effect of temperature was studied in a range of $25^{\circ} \mathrm{C}$ to $55^{\circ} \mathrm{C}$ and the remaining particle were kept constant. The removal efficiency decrease with an increase in temperature and good separation of cobalt from nickel was illustrated in fig. cobalt removal percentage decreased from $96 \%$ to $85 \%$ and nickel decreased from $37 \%$ to $21 \%$ as shown in Fig. 10. Is due to the mobility and competition of cobalt and nickel ions onto modified clinoptilolites $[12 ; 14]$. The maximum temperature was found to be $25^{\circ} \mathrm{C}$ with $96 \%$ of cobalt and $37 \%$ of nickel percentage recovery.

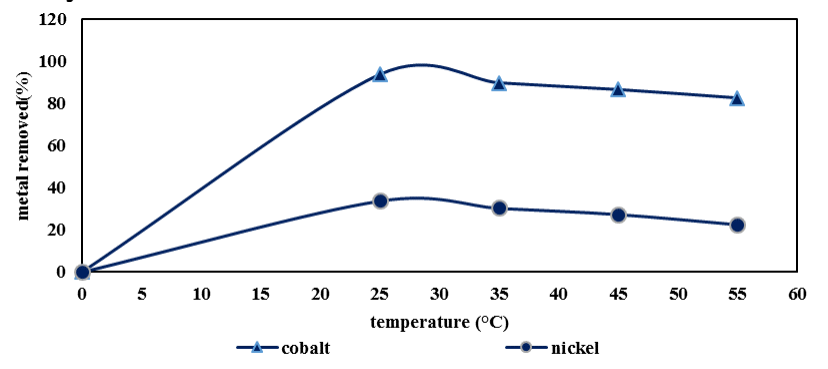

Fig. 10. Effect of temperature on the removal of cobalt and nickel onto modified clinoptilolites

\section{J. Effect of Adsorption Isotherm}

Adsorption isotherm explains the relationship between the imounts of cobalt and nickel ions adsorbed onto modified :linoptilolites for the design of the process.

- Langmuir isotherm (see Eq. 5)

$$
q_{e}=\frac{q_{m} K_{L} C_{t}}{1+K_{L} C_{t}}
$$

where $C_{t}$ equilibrium metal concentration, $q_{L}$ adsorption capacity maximum (mg.g $\left.{ }^{-1}\right), \mathrm{K}_{\mathrm{L}}$ Langmuir constant $\left({\mathrm{L} . \mathrm{mg}^{-1}}^{-1}\right)$ and $\mathrm{q}_{\mathrm{t}}$ is the amount of metal ion adsorbed at equilibrium $\left(\mathrm{mg} \cdot \mathrm{g}^{-1}\right)$ at a given temperature.

- Freundlich isotherm (see Eq. 6)

$$
q_{e}=K_{F} C_{t}^{\frac{1}{n}}
$$


where $\mathrm{q}_{\mathrm{t}}$ is the amount of metal ion adsorbed at equilibriun (mg.g-1), $\mathrm{K}_{\mathrm{F}}$ Freundlich equilibrium constant and $\mathrm{C}$ equilibrium metal concentration.

TABLE I:

PARAMETER VALUES OF ISOTHERM MODEL

\begin{tabular}{ccccccc}
\hline \hline Metal & Isotherm model & Parameters & $25^{\circ} \mathrm{C}$ & $35^{\circ} \mathrm{C}$ & $45^{\circ} \mathrm{C}$ & $55^{\circ} \mathrm{C}$ \\
\hline Cobalt & Freundlich & $\mathrm{n}$ & 3.86 & 2.74 & 2.54 & 2.2 \\
& & $\mathrm{R}^{2}$ & 0.94 & 0.93 & 0.94 & 0.9 \\
& & $\mathrm{~K}_{\mathrm{F}}$ & 37.70 & 17.67 & 11.22 & 10.48 \\
& \multirow{2}{*}{ Langmuir } & $\mathrm{q}_{\mathrm{m}}$ & 121.95 & 99.00 & 73.54 & 61.34 \\
& & $\mathrm{R}^{2}$ & 0.99 & 0.98 & 0.98 & 0.99 \\
& & $\mathrm{~K}_{\mathrm{L}}$ & 0.13 & 0.12 & 0.11 & 0.11 \\
Cobalt & Freundlich & $\mathrm{n}$ & 1.85 & 1.81 & 1.75 & 1.70 \\
& & $\mathrm{R}^{2}$ & 0.95 & 0.93 & 0.95 & 0.94 \\
& & $\mathrm{~K}_{\mathrm{F}}$ & 1.99 & 1.90 & 1.20 & 1.18 \\
& \multirow{2}{*}{ Langmuir } & $\mathrm{q}_{\mathrm{m}}$ & 47.84 & 46.39 & 30.30 & 24.87 \\
& & $\mathrm{R}^{2}$ & 0.97 & 0.96 & 0.97 & 0.97 \\
& & $\mathrm{~K}_{\mathrm{L}}$ & 0.02 & 0.02 & 0.02 & 0.01 \\
\hline \hline
\end{tabular}

Table I shows the experimental data obtained from the separation of cobalt from nickel ions onto modified clinoptilolites fitted well in Langmuir model with high correlation coefficient $\left(\mathrm{R}^{2}\right)$ and maximum adsorption capacity for cobalt 121.95 and nickel 47.39. modified clinoptilolites [14].

\section{K. Kinetic Studies}

The kinetic study plays an important role because it gives important insight of the reaction mechanism:

- Pseudo first order model (see Eq. 7)

$$
\frac{d_{q}}{d_{t}}=K_{a}\left(q_{x}-q_{t}\right)
$$

- Pseudo second order model (see Eq. 7)

$$
\frac{d_{q}}{d_{t}}=K_{b}\left(q_{x}-q_{t}\right)^{2}
$$

where $\mathrm{K}_{\mathrm{a}}$ is the rate constant of pseudo first order model and $\mathrm{kb}$ is rate constant of the pseudo second order model $\left(\mathrm{hr}^{-1}\right), \mathrm{q}_{\mathrm{x}}$ is the amount of metal ion absorbed at time $t\left(\mathrm{mg} \mathrm{g}^{-1}\right)$ and $\mathrm{q}_{\mathrm{t}}$ is the amount of metal absorbed at equilibrium $\left(\mathrm{mg} \cdot \mathrm{g}^{-1}\right)$.

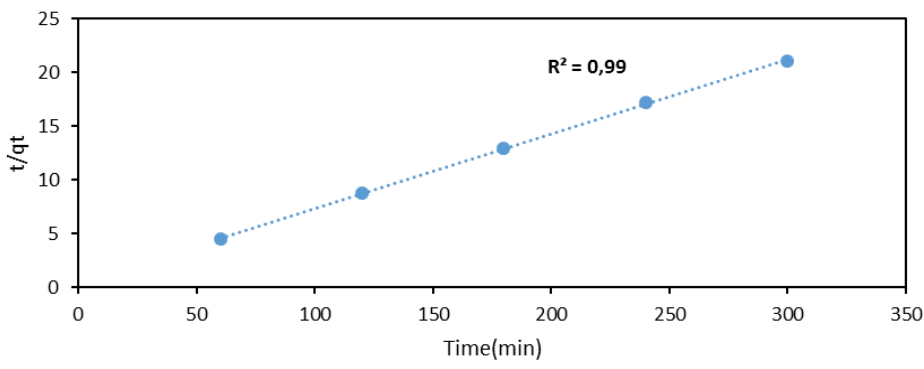

Fig. 11. Kinetics for cobalt removal onto modified clinoptilolites

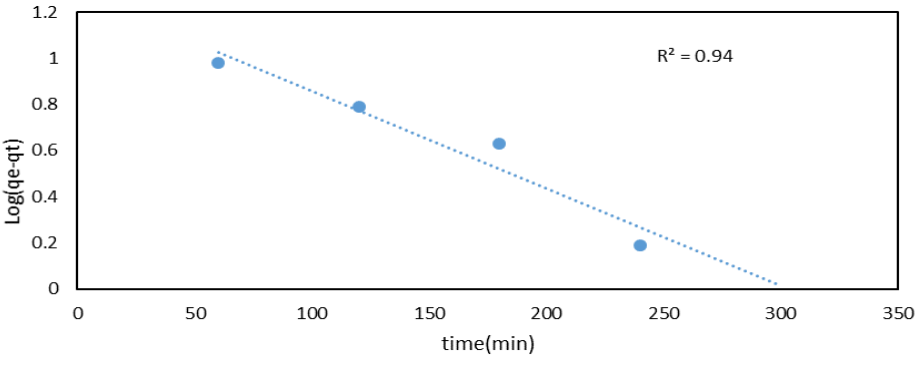

Fig. 12. Kinetics for cobalt removal onto modified clinoptilolites

Table II gives the values parameters of pseudo first and pseudo second order kinetic model. It was observed that the pseudo second order described well the kinetic model data with $\left(\mathrm{R}^{2}\right)$ correlation coefficient was 0.99 (Borandegi \& Nezamzadeh-Ejhieh, 2015).

TABLE II: PARAMETER VALUES OF KINETIC MODEL

\begin{tabular}{clclc}
\hline \hline Metal & \multicolumn{2}{l}{ Pseudo first order } & \multicolumn{2}{c}{ Pseudo second order } \\
& \multicolumn{2}{c}{} & & \\
\hline Cobalt & $\mathrm{q}_{\mathrm{e}}(\mathrm{mg} / \mathrm{g})$ & 53.30 & $\mathrm{q}_{\mathrm{e}}(\mathrm{mg} / \mathrm{g})$ & 100.1 \\
& $\mathrm{~K}_{1}\left(\mathrm{~min}^{-1}\right)$ & 2.89 & $\mathrm{~K}_{2}(\mathrm{~g} / \mathrm{mg} \cdot \mathrm{min})$ & 0.014 \\
& $\mathrm{R}^{2}$ & 0.89 & $\mathrm{R}^{2}$ & 0.99 \\
Nickel & $\mathrm{q}_{\mathrm{e}}(\mathrm{mg} / \mathrm{g})$ & 8.81 & $\mathrm{q}_{\mathrm{e}}(\mathrm{mg} / \mathrm{g})$ & 18.37 \\
& $\mathrm{~K}_{1}\left(\mathrm{~min}^{-1}\right)$ & 2.91 & $\mathrm{~K}_{2}(\mathrm{~g} / \mathrm{mg} \cdot \mathrm{min})$ & 0.020 \\
& $\mathrm{R}^{2}$ & 0.91 & $\mathrm{R}^{2}$ & 0.99 \\
\hline \hline
\end{tabular}

L. Thermodynamic studies

$$
\Delta G^{o}=-R T \ln K_{d}
$$

$\mathrm{K}_{\mathrm{d}}$ is equilibrium constant that can be used to determine the thermodynamic parameters $\left(\mathrm{H}^{\circ}\right)$ enthalpy, $\left(\mathrm{S}^{\mathrm{o}}\right)$ entropy and $\left(\mathrm{G}^{\mathrm{o}}\right)$ the change in free energy.

where $\mathrm{K}_{\mathrm{d}}$ is the distribution coefficient $\left(\mathrm{mLg}^{-1}\right)$, $\mathrm{R}(8.314$ $\left.\mathrm{Jmol}^{-1} / \mathrm{K}\right)$ universal gas constant and $\mathrm{T}$ is the temperature $\left({ }^{\circ} \mathrm{K}\right)$.

$$
\begin{aligned}
& \ln K_{d}=\frac{\Delta S}{R}-\frac{\Delta H}{R T} \\
& \Delta G=\Delta H-T \Delta S \\
& K_{d}=\frac{q_{e}}{C_{e}}=\frac{\left(C_{a}-C_{b}\right)}{C_{a}} \times \frac{V}{M}
\end{aligned}
$$

where $C_{a}$ and $C_{b}$ are the initial ion concentration and final ion concentration of the solution, respectively and $\mathrm{V}$ and $\mathrm{M}$ are the volume of solution $(\mathrm{mL})$ and amount of sorbent $(\mathrm{g})$, respectively

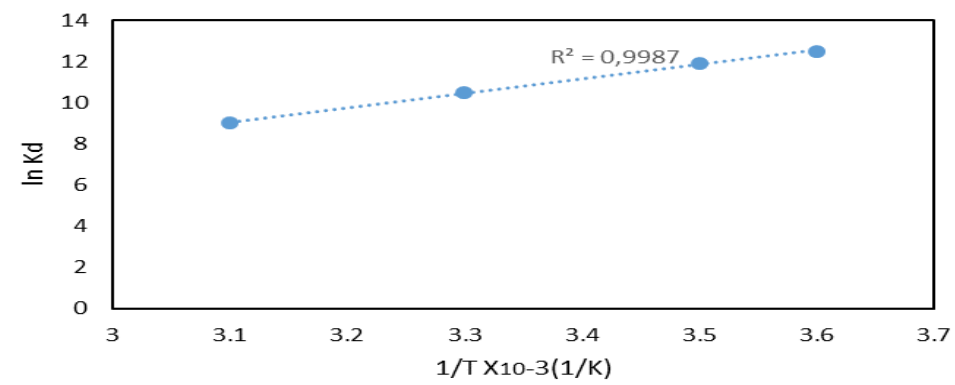

Fig. 13. Linearized 
TABLE III: THERMODYNAMIC PARAMETERS FOR COBALT REMOVAL ONTO MODIFIED CLINOPTILOLITE

\begin{tabular}{lrrrr}
\hline \hline $\begin{array}{l}\text { Temperature }(\mathrm{K}) \\
\mathrm{K})\end{array}$ & $\ln \mathrm{K}_{\mathrm{d}}$ & $\Delta \mathrm{G}(\mathrm{kJ} / \mathrm{mol} \mathrm{K})$ & $\Delta \mathrm{H}(\mathrm{kJ} / \mathrm{mol} \mathrm{K})$ & $\Delta \mathrm{S}(\mathrm{kJ} / \mathrm{mol}$ \\
\hline 298 & 12.39 & -59.71 & & \\
308 & 11.42 & -59.04 & -72.45 & -50.47 \\
318 & 10.87 & -58.74 & & \\
328 & 9.67 & -58.79 & & \\
\hline \hline
\end{tabular}

The results in Table III show that $\Delta \mathrm{G}^{0}$ become less negative with the increase of the temperature that indicate the process is less favorable at high temperatures. The negative $\Delta G^{\circ}$ values at different temperatures indicated that the reaction was thermodynamically feasible and spontaneous process. The negative $\Delta \mathrm{H}^{\mathrm{o}}$ value confirmed that the reaction is exothermic and the negative value of $\Delta S^{o}$ indicate that after cobalt adsorption on the modified clinoptilolites total entropy of the system decreased degree of disorderliness at the solid/liquid interface during the adsorption [14].

\section{CONCLUSION}

This study indicates that the separation of cobalt and nickel using modified clinoptilolites with EDTA and succinic acid depends on cobalt initial concentration and some other parameters such as $\mathrm{pH}$, mass of the adsorbent and temperature. Modified clinoptilolites can separate cobalt and nickel using ion exchange process. Particle size of the modified clinoptilolites showed also a significant role on the removal efficiency.

The characterization of clinoptilolites before and after modification was done using Scanning Electron Microscope (SEM), Fourier Transform Infrared spectroscopy (FTIR), X-ray fluorescence (XRF) and X-ray diffraction (XRD). The results showed that the separation of cobalt from nickel strongly depend on $\mathrm{pH}$, initial concentration, mass of the adsorbent, particle sizes and temperature. High separation efficiency was obtained under following conditions $\mathrm{pH}$ 6, initial concentration $600 \mathrm{mg} / \mathrm{L}$, mass of the adsorbent $10 \mathrm{~g}$, particle sizes $1 \mathrm{~mm}$ and temperature $25^{\circ} \mathrm{C}$. The equilibrium sorption isotherms were analyzed by the Langmuir and Freundlich. The results showed that Langmuir isotherm describes better the adsorption process. The pseudo-first and second order model were used in analyzing kinetic data, absorption kinetics obeyed the second Pseudo order model that indicate that the rate limiting step for the process involves chemical reaction. Thermodynamic parameters such as Gibb's free energy change $\left(\Delta G^{0}\right)$, enthalpy change $\left(\Delta \mathrm{H}^{\mathrm{o}}\right)$ and entropy change $\left(\Delta \mathrm{S}^{\mathrm{o}}\right)$ were calculated and negative results revealed that the process was spontaneous and exothermic.

\section{ACKNOWLEDGMENT}

The authors gratefully acknowledge the support received from the Vaal University of Technology.

\section{REFERENCES}

[1] D.W. Nyembe, B.B. Mamba and A.F. Mulaba-Bafubiandi. "Adsorption mechanism of $\mathrm{Co}^{2+}$ and $\mathrm{Cu}^{2+}$ from aqueous solutions using natural clinoptilolite: equilibrium and kinetics studies”. J. Appl. Sci., vol. 10, pp. 599-610, 2010.

[2] M.E Asio "Use of clinoptilolites for the removal of nickel ions from water: kinetics and thermodynamics". J. Hazard. Mat., vol. 150, pp. 587-595, 2009.

[3] T. Z. Sadyrbaeva Riga. "Separation of cobalt (II) from nickel (II) by a hybrid liquid membrane- electro dialysis process using anion exchange carriers", Desalination, vol.365, pp. 167-175, 2015.

[4] F. Douglas, "Cobalt- nickel separation in hydrometallurgy, chemistry for sustainable development", vol. 12, pp. 81-91, 2004.

[5] V. Coman. B. Robotin and P. Ilea, P (2013)" Nickel recovery/removal from industrial wastes, Resources", Conservation and Recycling, vol. 73, pp. 229-238, 2013.

[6] Al Dwairi and Rawajfeh, "Removal of cobalt and nickel from wastewater by using jordan low-cost zeolite and bentonite", Chemical Technology and Metallurgy, vol. 6, pp. 69-76, 2012.

[7] M. Culfaz and M. Yagiz, M. "Ion exchange properties of natural clinoptilolite". Separation and Purification Techn., vol. 37, pp. 93-105, 2004.

[8] J. Kabuba and A.F. Mulaba-Bafudiandi, "Modelling of Co-Cu elution from clinoptilolites using neural network". World Academy of Science Engineering and Technology, vol. 68, pp. 1222-1225, 2012.

[9] T. Ünald, I. Mizrak and S. Kadir, "Physicochemical characterisation of natural K-clinoptilolites and heavy-metal forms from Gördes", Molec. Structure, vol., pp. 349-358, 2013.

[10] J. Ran, L. Wu, Y. He, Z. Yang, Y. Wang, Ch. Jiang, L. Ge, E. Bakangura, T. Xun. "Ion exchange membranes: New developments and applications", Membrane Sci., vol. 13, pp. 267-291, 2017.

[11] N. Öztürk, F. Ucun, A.D. Muhtar and S. Bahçeli, (2009) Infrared and SEM analyses of polyethyleneglycol-400 adsorbed on zeolites $\mathrm{NaA}, \mathrm{CaA}$, $\mathrm{NaX}$ and NaY, molecular of structures, vol. 14, pp. 35-38, 2009.

[12] Borandegi and Nezamzadeh-Ejhieh, 2015.

[13] M.V. Dinu and E. S. Dragan, "Evaluation of $\mathrm{Cu}^{2+}, \mathrm{Co}^{2+}$ and $\mathrm{Ni}^{2+}$ ions removal from aqueous solution using a novel chitosan/clinoptilolites composite: Kinetics and isotherms Maria, chemical engineering, vol. 16, pp. 157-163, 2010.

[14] L. Zhang, Y. Zeng Y and Z. Cheng. "Removal of heavy metal ions using chitosan and modified chitosan", Molecular Liquids, vol. 17, pp.175-191, 2016. 